\title{
Comparison of cardiac dysfunction in thalassemia major patients using deferoxamine or deferiprone as an iron-chelating agent
}

\author{
Rosalina Josep, Pustika Amalia Wahidiyat, Partini Pudjiastuti Trihono, Piprim B. Yanuarso
}

\begin{abstract}
Background In thalassemia major (TM) patients, major mortality is due to cardiac hemosiderosis. Several types of iron chelating agent available recently are given to overcome this problem

Objective To compare cardiac dysfunction in thalassemia major patients who used subcutaneous deferoxamine (DFO) to those who used oral deferiprone (DFP) as an iron-chelating agent.

Methods This cross-sectional study was held at the Thalassemia Center, Department of Child Health-Cipto Mangunkusumo Hospital (DCH-CMH), Jakarta. We included TM patients aged $10-18$ years with a mean pre-transfused hemoglobin level of $\geq 7$ $\mathrm{g} / \mathrm{dL}$ in the prior year, and who had used DFO or DFP for at least 1 year with good compliance, at a standard dose of DFO at $40-60 \mathrm{mg} / \mathrm{kg} / \mathrm{day}$ for 5 days a week or DFP at $50-100 \mathrm{mg} / \mathrm{kg} / \mathrm{day}$. We excluded TM patients with congenital heart disease or overt heart failure. Trans-thoracal echocardiography was performed at the Integrated Cardiac Service, CMH by a pediatric cardiologist using the conventional method and tissue Doppler imaging (TDI) consecutively, and within 2 weeks of the subject's receiving a packed red blood cell (PRBC) transfusion. The 57 TM subjects consisted of 19 DFO users and 38 DFP users.

Results In our subjects, diastolic dysfunction was more commonly seen than systolic dysfunction, especially moderate diastolic dysfunction. In the DFO group, diastolic dysfunction only was detected in $3 / 19$ subjects, systolic dysfunction only in $1 / 19$ subjects, and both diastolic and systolic dysfunction in 15/19 subjects. None of the DFO users had normal cardiac function. In the DFP group, diastolic dysfunction only was seen in $6 / 38$ subjects, and both diastolic and systolic dysfunction in 30/38 subjects, while 2/38 subjects had normal cardiac function.

Conclusion Diastolic and/or systolic dysfunction was detected in the majority of subjects, but with preserved global cardiac function. We found that cardiac dysfunction was not significantly different in the two iron chelator groups. For all subjects, diastolic dysfunction
\end{abstract}

was seen in $89 \%$ of cases, while systolic dysfunction was detected in $77 \%$ of cases. [Paediatr Indones. 2012;52:272-9].

Keywords: thalassemia major, deferoxamine, deferiprone, diastolic dysfunction, systolic dysfunction, conventional echocardiography, TDI

$\mathrm{T}$ Thalassemia is the most common genetic disorder worldwide. ${ }^{1}$ Chronic hemolytic anemia forces TM patients to depend on life-long transfusion therapy for their survival. ${ }^{2}$ Mortality in TM is mainly (up to $71 \%$ ) caused by cardiac hemosiderosis. ${ }^{3}$ Cardiac dysfunction, which leads to cardiomyopathy, mostly begins in the second decade of life..$^{2,4-6}$ Subclinical cardiac iron deposition is typically silent for many years. Progressive deterioration occurs rapidly by the time

From the Department of Child Health, University of Indonesia Medical School, Cipto Mangunkusumo Hospital, Jakarta, Indonesia

Reprint requests to: Rosalina Josep, Department of Child Health, University of Indonesia Medical School, Jalan Salemba Raya No.6, Jakarta 10430, Indonesia. Tel +62-21-3919016. E-mail: rosaprawira@ hotmail.com 
heart failure manifests clinically. High mortality due to cardiac hemosiderosis suggests that the condition is not recognized until the advanced stage of the disease. By that time it is too late for effective intervention. ${ }^{6}$

Regular and adequate iron-chelation therapy can prevent and improve cardiac dysfunction in TM patients. ${ }^{7-8}$ Several iron-chelating agents are available, but controversies remain on which iron-chelating agents better preserve cardiac function. ${ }^{7,9-17}$ DFP, as the world's first oral iron-chelating agent, has been used widely at the Thalassemia Center, DCH-CMH since 2007, while subcutaneous DFO as the world's first iron chelating agent has been used since 1987.18 $\mathrm{DFO}$ is a hexadentate chelator and has an excellent affinity to plasma free iron. DFP is a bidentate chelator with a lower molecular weight than that of DFO (only $1 / 3$ that of DFO). DFP's lipophilic nature allows it to more easily penetrate cells to bind intracellular free iron. ${ }^{9-10}$

The gold standard tool for detecting cardiac hemosiderosis in TM patients are T2* MRI images. ${ }^{19-22}$ Since T2* MRI is costly and not widely available, echocardiography remains the preferred method of evaluation. ${ }^{23-25}$ In conventional echocardiography, signals are from transmitral blood flow, while in TDI, signals are from myocardial wall movement. ${ }^{26-28}$ Aypar et al. ${ }^{29}$ found that pulsed-wave TDI had high sensitivity and specificity when correlated with $\mathrm{T} 2$ * MRI in predicting myocardial siderosis in TM patients with normal systolic function.

The objective of this study was to compare the proportion of cardiac dysfunction in TM patients who had used subcutaneous DFO to those who used oral DFP as iron-chelating agents. DFP subjects were expected to have fewer echocardiographic abnormalities than DFO subjects.

\section{Methods}

This cross-sectional study was conducted at the Thalassemia Center, DCH-CMH, Jakarta, from March to May 2011. We included TM patients aged 10-18 years with a mean pre-transfused hemoglobin level of $\geq 7 \mathrm{~g} / \mathrm{dL}$ in the past year, and who had used DFO or DFP for at least 1 year with good compliance, at a standard dose of DFO $40-60 \mathrm{mg} / \mathrm{kg} / \mathrm{day}$ for 5 days a week or DFP $50-100 \mathrm{mg} / \mathrm{kg} /$ day. TM patients with congenital heart disease or overt heart failure were excluded. Trans-thoracal echocardiography was performed with informed consent at the Integrated Cardiac Service, $\mathrm{CMH}$ using a General Electric Vivid-7 (1.5 - $4 \mathrm{MHz}$ transducer) by a pediatric cardiologist using conventional and TDI methods consecutively, and within 2 weeks of PRC transfusion. The required sample size was calculated by hypothesis testing against a two proportion formula $(\alpha=5 \%$, $\beta=20 \%, P_{1}-P_{2}=20 \%, n=35$ for each group). ${ }^{30}$ This study was approved by the Ethics Committee of the University of Indonesia Medical School. Data was analyzed using SPSS for Windows version 11.5.

In this study, only left heart function was assessed, since left-sided heart failure is more common than right-sided heart failure in young populations, and five-fold more common than right-sided heart failure in TM patients. ${ }^{31}$ Conventional echocardiography parameters were used, including ejection fraction (EF, \%) to represent systolic function and E/A ratio to describe diastolic function. The TDI parameters used were $\mathrm{Sa}$ (myocardial velocity in $\mathrm{cm} / \mathrm{s}$ during systole), Ea (myocardial velocity in $\mathrm{cm} / \mathrm{s}$ during early diastole), and $\mathrm{Aa}$ (myocardial velocity in $\mathrm{cm} / \mathrm{s}$ during late diastole), all of which were taken at the mid-septal and mid-lateral left ventricular locations..$^{32-37}$

In the TDI method, systolic dysfunction was determined based on receiver operating characteristic (ROC) curve of $\mathrm{EF} \leq 55 \%$ against mid-septal $\mathrm{Sa}<8.5$ $\mathrm{cm} / \mathrm{s}$ (sensitivity $83 \%$, specificity $43 \%$ ) or mid-lateral Sa $<10 \mathrm{~cm} / \mathrm{s}$ (sensitivity $83 \%$, specificity $29 \%$ ) in all subjects.

The presence of systolic dysfunction was determined by either low EF or low Sa. Combined echocardiography parameters could not be used to determine grade of systolic dysfunction.

In the TDI method, diastolic dysfunction cut-off point criteria was based on Ea value, which correlated with abnormal T2* MRI as the gold standard in predicting cardiac hemosiderosis in a study by Aypar et al. Mid-septal Ea $<13 \mathrm{~cm} / \mathrm{s}$ had 100\% sensitivity with $92 \%$ specificity, while mid-lateral Ea $<20 \mathrm{~cm} / \mathrm{s}$ had $100 \%$ sensitivity with $83 \%$ specificity. $^{29}$

We determined the presence of diastolic dysfunction by one of two ways:

1. Single parameter: either abnormal E/A ratio or low Ea 
2. Combined parameters: high E/Ea ratio

Grading of diastolic dysfunction was further determined by $\mathrm{E} / \mathrm{Ea}$ ratio and $\mathrm{E} / \mathrm{A}$ ratio as shown in Table 1.

\section{Results}

A total of 57 TM subjects were recruited; there were 19 subjects in the DFO group and 38 subjects in the DFP group. Table 2 describes the subjects' characteristics of both groups.

The cardiac dysfunction test results of the left side of the heart by iron chelator groups is described in Table 3 and Table 4.

The majority of subjects had both diastolic and systolic dysfunction (45/57 total subjects), while 9/57 total subjects had diastolic dysfunction only, 1/57 total subjects had systolic dysfunction only, and only 2/57 total subjects had normal cardiac function. In this study, the proportion of subjects with subclinical cardiac dysfunction were not significantly different between the DFO and DFP groups.

Table 1. Cardiac dysfunction criteria based on echocardiography findings

\begin{tabular}{|c|c|c|}
\hline & Diastolic dysfunction & Systolic dysfunction \\
\hline Conventional echocardiography & E/A ratio $<1.43$ or $>2.33$ & $\mathrm{EF} \leq 55 \%$ \\
\hline TDI & $\begin{array}{l}\text { Mid-septal Ea }<13 \text { or } \\
\text { Mid-lateral Ea }<20(\mathrm{~cm} / \mathrm{s})\end{array}$ & $\begin{array}{l}\text { Mid-septal Sa }<8.5 \text { or } \\
\text { Mid-lateral } \mathrm{Sa}<10(\mathrm{~cm} / \mathrm{s})\end{array}$ \\
\hline $\begin{array}{l}\text { Combination methods }{ }^{37,39-41} \\
\text { (conventional and TDI) }\end{array}$ & $\begin{array}{l}\text { Septal or lateral E/Ea }>8 \\
\text { Grading of diastolic dysfunction } 37,39-41: \\
\text { Mild dysfunction } \\
\text { (impaired relaxation): } \\
\text { E/Ea }<8 \text { with } E / A<1.43 \\
\text { Moderate dysfunction (pseudonormal } \\
\text { pattern): } \\
\text { E/Ea }>8 \text { with normal E/A } \\
\text { Severe dysfunction } \\
\text { (restrictive pattern): } \\
\text { E/Ea }>8 \text { with E/A }>2.33\end{array}$ & \\
\hline
\end{tabular}

Table 2. Demographic and clinical characteristics of subjects by iron-chelator group

\begin{tabular}{|c|c|c|c|}
\hline \multirow[t]{2}{*}{ Characteristics } & \multicolumn{2}{|c|}{ Chelator groups } & \multirow{2}{*}{$\begin{array}{l}\text { Total } \\
(n=57)\end{array}$} \\
\hline & DFO $(n=19)$ & DFP $(n=38)$ & \\
\hline \multicolumn{4}{|l|}{ Sex, $n$} \\
\hline Male & 5 & 20 & 25 \\
\hline Female & 14 & 18 & 32 \\
\hline \multicolumn{4}{|c|}{ Nutritional status*, $\mathrm{n}$} \\
\hline Malnourished & 15 & 30 & 45 \\
\hline Normal weight & 4 & 5 & 9 \\
\hline Overweight & 0 & 3 & 3 \\
\hline \multicolumn{4}{|c|}{ Type of thalassemia major, $n$} \\
\hline - $\beta$ homozygote & 10 & 22 & 32 \\
\hline$-\beta / \mathrm{HbE}$ & 9 & 16 & 25 \\
\hline \multicolumn{4}{|c|}{ Mean duration of illness, $n$} \\
\hline$\geq 10$ years & 14 & 27 & 41 \\
\hline$<10$ years & 5 & 11 & 16 \\
\hline \multicolumn{4}{|c|}{$\begin{array}{l}\text { Mean serum ferritin within } \\
\text { most recent year, } \mathrm{n}\end{array}$} \\
\hline$\geq 2500 \mathrm{ng} / \mathrm{mL}$ & 18 & 28 & 46 \\
\hline$<2500 \mathrm{ng} / \mathrm{mL}$ & 1 & 10 & 11 \\
\hline
\end{tabular}

* measured by mid-upper arm circumference 
Rosalina Josep et al: Cardiac dysfunction in thalassemia major patients using iron-chelating agents

Table 3. Cardiac dysfunction by iron chelator group based on echocardiography modality

\begin{tabular}{|c|c|c|c|c|c|}
\hline & \multicolumn{2}{|c|}{ Echocardiogram } & \multirow[t]{2}{*}{$P$ value } & \multirow[t]{2}{*}{$\mathrm{RR}$} & \multirow[t]{2}{*}{$\mathrm{Cl} 95 \%$} \\
\hline & Dysfunctional & Normal & & & \\
\hline \multicolumn{6}{|c|}{ Conventional echocardiography } \\
\hline DFO & 7 & 12 & 0.922 & 1.08 & $0.52-2.25$ \\
\hline DFP & 13 & 25 & & & \\
\hline \multicolumn{6}{|c|}{ Systolic function *) } \\
\hline DFO & 1 & 18 & 0.652 & 0.40 & $0.05-3.19$ \\
\hline DFP & 5 & 33 & & & \\
\hline \multicolumn{6}{|l|}{ TDI } \\
\hline \multicolumn{6}{|c|}{ Diastolic function *) } \\
\hline DFO & 17 & 2 & 0.703 & 1.10 & $0.88-1.36$ \\
\hline DFP & 31 & 7 & & & \\
\hline \multicolumn{6}{|c|}{ Systolic function *) } \\
\hline DFO & 16 & 3 & 0.510 & 1.14 & $0.87-1.50$ \\
\hline DFP & 28 & 10 & & & \\
\hline \multicolumn{6}{|c|}{ Combined evaluation methods } \\
\hline DFO & 16 & 3 & 0.389 & 0.91 & $0.74-1.13$ \\
\hline DFP & 35 & 3 & & & \\
\hline
\end{tabular}

Note : *) Fisher's exact test

Table 4. Proportion of subjects with cardiac dysfunction by iron chelator group

\begin{tabular}{|c|c|c|c|c|c|}
\hline & \multicolumn{2}{|c|}{$\begin{array}{c}\text { DFO } \\
(n=19)\end{array}$} & \multicolumn{2}{|c|}{$\begin{array}{c}\text { DFP } \\
(\mathrm{n}=38)\end{array}$} & \multirow[t]{2}{*}{$P$ value } \\
\hline & $\mathrm{n}$ & $(\%)$ & $\mathrm{n}$ & $(\%)$ & \\
\hline Normal & 0 & (0) & 2 & (5) & 0.548 \\
\hline Diastolic dysfunction only & 3 & $(16)$ & 6 & $(16)$ & 1.000 \\
\hline Systolic dysfunction only & 1 & $(5)$ & 0 & $(0)$ & 0.333 \\
\hline Diastolic and systolic dysfunction & 15 & $(79)$ & 30 & $(79)$ & 1.000 \\
\hline
\end{tabular}

\section{Discussion}

In our study, female subjects were almost equal to male subjects ( 32 vs 25 subjects). However, among male subjects, the ratio of DFP to DFO use was disproportionate at 4:1. In general, the oral chelator was preferred over the subcutaneous chelator, because the oral route is more practical, more comfortable, non-invasive and not painful. DFP requires no special administration procedure nor restriction of daily activities. Patients' compliance to the oral chelator was better than that of the subcutaneous chelator, hence there were fewer DFO users.

The mean ages for the DFO and DFP groups were similar: 13.9 (SD 2.3) years and 14 (SD 2.3) years, respectively. Most subjects (41/57) had suffered from thalassemia for more than 10 years. Duration of illness in each DFO group ranges 5.3 - 16.4 years, while that of the DFP group was 4.3 - 17.8 years. Longer duration of illness and and greater number of PRBC transfusions led to a higher risk of transfusional hemosiderosis. Serum ferritin in ranges within the most recent year among DFO subjects was 1663 - $11303 \mathrm{ng} / \mathrm{mL}$, while in DFO group was 1005 $9906 \mathrm{ng} / \mathrm{mL}$. The majority of subjects, regardless of iron-chelating agent used, had severe iron overload (mean serum ferritin of $\geq 2500 \mathrm{ng} / \mathrm{mL}$ ). A previous study by Silvilairat et al. ${ }^{42}$ reported that increasing E/ Ea ratio reflects severe cardiac iron overload. They also showed that cardiac function in TM subjects could be preserved if serum ferritin was $<2500 \mathrm{ng} /$ $\mathrm{mL}$. However, we found that nine subjects with mean serum ferritin of $<2500 \mathrm{ng} / \mathrm{mL}$ (1 DFO, 8 DFP) already had cardiac abnormalities. The lowest serum ferritin in this study was $1005 \mathrm{ng} / \mathrm{mL}$, in a 10.8 year-old boy who had $\beta$-major thalassemia for 8.3 years and had used DFP in the last 1.4 years. He had received DFO 
Rosalina Josep et al: Cardiac dysfunction in thalassemia major patients using iron-chelating agents

before it was replaced by DFP. He had severe diastolic dysfunction with normal EF. Bosi et al..$^{43}$ reported a weak negative correlation between serum ferritin and EF. Serum ferritin, as an acute phase reactant, could be elevated due to inflammation, malignancy, or liver diseases. ${ }^{44}$ Serum ferritin reflects only $1 \%$ of total body iron. ${ }^{3}$ Serum ferritin cannot reliably predict cardiac iron burden. Piga et al. ${ }^{45}$ showed that thalassemia patients with cardiac dysfunction had high transferrin saturation $(>70 \%)$ and high non-transferrin bound iron (NTBI) levels, compared to thalassemia patients without cardiac dysfunction.

The DFO group had used DFO for a longer duration than DFP subjects had used DFP. Ranges duration of DFO use was $1-11.3$ years, while median duration of DFP use was $1-3.7$ years. In the Thalassemia Center at DCH-CMH, DFO had been used since 1987, 20 years prior to DFP use. ${ }^{18}$ In our study, the mean dose of subcutaneous DFO was 42.8 (SD 4.4) $\mathrm{mg} / \mathrm{kg} /$ day for 5 days a week, while mean dosage of oral DFP was 70.2 (SD 7.6) $\mathrm{mg} / \mathrm{kg} / \mathrm{day}$ within the most recent year.

Both iron chelators have short half-lives (DFO 20 minutes and DFP 2-3 hours), therefore, patients compliance is crucial to prevent and manage cardiac dysfunction due to iron overload. ${ }^{10}$ Piga et al. ${ }^{11}$ and Delea et al. ${ }^{46}$ reported that patients had better compliance with DFP than with DFO use. We also found that patient compliance was slightly better with the oral chelator than the subcutaneous chelator, although this difference was not statistically nor clinically significant (average DFO compliance 85.8 (SD 6.5)\% and average DFP compliance 87.3 (SD 6.1)\%. TM patient education about their illness and its long-term complications, including cardiac hemosiderosis, is needed to motivate them to comply in taking the iron-chelating agents.

In our subjects, cardiac dysfunction detected by echocardiography could have been diastolic, systolic, or a combination of both diastolic and systolic dysfunction. Conventional echocardiography revealed normal global cardiac function in the majority of subjects. However, the TDI method revealed significant cardiac dysfunction in the majority of subjects. Diastolic dysfunction was found in 48/57 (84\%) of all subjects, while systolic dysfunction was detected in $44 / 57(77 \%)$ of all subjects. We found that the presence of either diastolic or systolic dysfunction was not significantly different between the two groups (all $P$ values $>0.05$ ). Low $E F$ of $\leq 55 \%$ was found in only $11 \%$ of the subjects ( 1 DFO and 5 DFP subjects). In both chelator groups, diastolic dysfunction was more commonly seen than systolic dysfunction.

A decrease in the regional myocardial wall velocity was typically found before any signs and symptoms of overt heart failure. Hence, TDI may be beneficial in early detection of regional abnormalities before global cardiac dysfunction occurs. Another benefit of TDI is in estimating the left ventricle end diastolic pressure (LVEDP) by E/Ea ratio. An increase in LVEDP is an early marker of diastolic dysfunction. An E/Ea ratio > 8 correlates with an elevation of LVEDP, according to Ommen et al. ${ }^{47}$ who correlated direct measurement of LVEDP through an invasive cathetherization procedure and $\mathrm{E} / \mathrm{E}$ a ratio by echocardiography. An increase in $\mathrm{E} /$ Ea ratio has been correlated to an increased clinical risk of heart failure. ${ }^{28}$

Iron deposition may trigger heart failure in TM patients. Iron overload in thalassemia is due to ineffective erythropoiesis, peripheral hemolysis, and an increase in iron absorption through the gastrointestinal tract, but the main cause is repetitive blood transfusions. Each PRBC unit contains 200-250 $\mathrm{mg}$ of iron. Repetitive transfusions saturate the body's transferrin, impairing its ability to bind iron. Iron toxicity occurs when free oxygen radicals are produced from free iron, the most toxic form of iron. Reactive oxygen species (ROS) cause perioxidative damage to cell structures, apoptosis of cardiomyocytes, and eventually cardiac dysfunction. ${ }^{2,19}$

In our study, diastolic dysfunction was more commonly seen than systolic dysfunction, similar to several other thalassemia studies ${ }^{48-52}$ in which left ventricle diastolic dysfunction usually preceded the onset of systolic dysfunction. Diastolic dysfunction in our subjects was classified as mainly moderate dysfunction (33/57), characterized by "normal" E/A ratio. This "normal" $\mathrm{E} / \mathrm{A}$ ratio in moderate diastolic dysfunction was a pseudo-normal pattern, because E/Ea ratio was increased when measured by the combined methods. Conventional echocardiography could not be used alone to detect moderate diastolic dysfunction. TDI was needed to confirm all the "normal" E/A ratios found by the conventional method, hence leading to different echocardiogram interpretations. 
Rosalina Josep et al: Cardiac dysfunction in thalassemia major patients using iron-chelating agents

In the DFO group, diastolic dysfunction only was detected in 3/19 subjects, systolic dysfunction only in $1 / 19$ subjects, and both diastolic and systolic dysfunction in 15/19 subjects. No DFO users had normal cardiac function. In the DFP group, diastolic dysfunction only was seen in $6 / 38$ subjects, both diastolic and systolic dysfunction in 30/38 subjects, while $2 / 38$ subjects had normal cardiac function. The occurrence of cardiac dysfunction, diastolic or systolic, between the two iron-chelator groups were not significantly different (all $\mathrm{P}$ values were $>0.05$ ).

We had expected less cardiac dysfunction in the DFP group than in the DFO group, but this was not the case. One reason could be that the majority of DFO users had changed to DFP use after its introduction in the Thalassemia Centre in 2007. According to data from the Thalassemia Center, from 2007 - 2011 about $65 \%$ of the thalassemia patients aged $10-18$ years changed their chelating agent from DFO to DFP. ${ }^{18}$ It is possible that subjects' cardiac dysfunction occured before the change in iron chelators. Furthermore, subclinical cardiac dysfunction may occur before patients enter their second decade of life, but we only recruited TM subjects aged 10-18 years, and grouped them according to the chelator they had taken by in the year prior to the study.

Maggio et al. ${ }^{15}$ explained that thalassemia patients have individual sensitivities to oxidative damage in their heart tissue due to iron overload. Differences at molecular level and in immunogenetic mechanisms influence the body's resistance to iron toxicity.

The majority of subjects in our study had significant subclinical cardiac dysfunction. Early recognition of these abnormalities before obvious clinical manifestations are seen is important in order to intervene earlier. Optimizing chelation therapy could reverse these abnormalities as much as possible in order to gain better quality of life and increase patients' survival rates.

Since this study was not longitudinal, all factors that might interact and influence the occurrence of cardiac dysfunction, as well as a cause-result relationship could not be explained extensively. Ideally, to determine which chelating agent is superior for protecting cardiac function, a longitudinal study must be done with all participants observed from the first time they receive chelation therapy, at a certain standard dosage, and then monitored regularly until they enter the second decade of life without any change in chelator type. In addtion to the relatively small sample size, especially in the DFO group, compliance levels were assessed only by interviewing subjects and their parents, which may be subject to recall bias.

In conclusion, diastolic and/or systolic dysfunction was detected in the majority of TM subjects, but with preserved global cardiac function. Cardiac dysfunction between the iron chelator groups was not significantly different. Among all thalassemia major patients diastolic dysfunction was seen in $89 \%$ of cases, while systolic dysfunction was detected in $77 \%$ of cases.

\section{Acknowledgments}

We thank Hardiono D. Pusponegoro, MD, and Evita B. Ifran, MD, for sharing all helpful suggestions and directing the study. Special gratitude goes to Rubiana Sukardi, MD, as the pediatric cardiologist who kindly performed all the echocardiography tests. We also thank Joedo Prihartono, MD, MPH, for his assistance with the statistical analysis in this study.

\section{References}

1. Weatherall DJ. Anaemia as a world health problem. In: Warrel DA, Cox TM, Firth JD, editors. Oxford textbook of medicine Ed.3. Oxford: Oxford University Press; 2001. p. 3463-82.

2. Kremastinos DT, Farmakis D, Aessopos A, Hahalis G, Hamodraka E, Tsiapras D, et al. B-thalassemia cardiomyopathy: history, present considerations, and future perspectives. Circ Heart Fail. 2010;3:451-8.

3. Pennell DJ. Iron overload and the heart. In: Cohen AR, Galanello R, Pennel DJ, Cunningham MJ, Vichinsky E, editors. Thalassemia. Hematology Am Soc Hematol Educ Program. 2004;1:14-34.

4. Permono B, Ugrasena IDG. Thalassemia. In: Permono B, Sutaryo, Ugrasena IDG, Windiastuti E, Abdulsalam M, editors. Buku ajar hematologi-onkologi anak. Jakarta: Badan Penerbit Ikatan Dokter Anak Indonesia; 2005. p. 64-84.

5. Aessopos A, Farmakis D, Deftereos S, Tsironi M, Tassiopoulos S, Moyssakis I, et al. Thalassemia heart disease: a comparative evaluation of thalassemia major and thalassemia intermedia. Chest. 2005;127:1523-30.

6. Wood JC, Enriquez C, Ghugre N, Otto-Duessel M, Aguilar 
Rosalina Josep et al: Cardiac dysfunction in thalassemia major patients using iron-chelating agents

M, Nelson MD, et al. Physiology and pathophysiology of iron cardiomyopathy in thalassemia. Ann N Y Acad Sci. 2005;1054:386-95.

7. Pepe A, Favilli B, Positano V, Cianciulli P, Spasiano A, Capra M, et al. Comparison of deferasirox, deferiprone and desferrioxamine effectiveness on myocardial iron concentrations and biventricular function by quantitative MRI in thalassemia major. [cited 2010 July 20]. Available from: ash.confex.com/ash/2008/webprogram/Paper 3749.html.

8. Maggio A, Vitrano A, Capra M, Cuccia L, Gagliardotto F, Filosa A, et al. Improving survival with deferiprone treatment in patients with thalassemia major: a prospective multicenter randomized clinical trial under the auspices of the Italian Society for Thalassemia and Hemoglobinopathies. Blood Cells Mol Dis. 2009;42:247-51.

9. Galanello R. New iron chelators. In: Cohen AR, Galanello R, Pennel DJ, Cunningham MJ, Vichinsky E, editors. Thalassemia. Hematology Am Soc Hematol Educ Program. 2004;1:14-34.

10. Cohen AR. New advances in iron chelation therapy. Hematology Am Soc Hematol Educ Program. 2006;1:42-7.

11. Piga A, Gaglioti C, Fogliacco E, Fernando T. Comparative effects of deferiprone $\&$ deferoxamine on survival $\&$ cardiac disease in patients with thalassemia major: a retrospective analysis. Haematologica. 2003;88:489-96.

12. Vichinsky E. Iron overload and iron chelation therapy in pediatric patients. US Hematology. 2009;2:64-7.

13. Pennell DJ, Berdoukas V, Karagiorga M, Ladis V, Piga A, Aessopos A, et al. Red cells: randomized controlled trial of deferiprone or deferoksamine in beta-thalassemia major patients with asymptomatic myocardial siderosis. Blood. 2006;107:3738-44.

14. Olivieri NF, Brittenham GM, Matsui D, Berkovitch M, Blendis LM, Cameron RG, et al. Iron chelation therapy with oral deferiprone in patients with thalassemia major. $\mathrm{N}$ Engl J Med. 1995;332:918-22.

15. Maggio A, D’Amico G, Morabito A, Capra M, Ciaccio C, Cianciulli P, et al. Deferiprone versus deferoxamine in patients with thalassemia major: a randomized clinical trial. Blood Cells Mol Dis. 2002;28:196-208.

16. Taher A, Sheikh-Taha M, Koussa S, Inati A, Neeman $\mathrm{R}$, Mourad F. Comparison between deferoxamine and deferiprone (L1) in iron-loaded thalassemia patients. Eur J Hematol. 2001;67:30-4.

17. Berdoukas V, Chouliaras G, Moraitis P, Zannikos K, Berdoussi $\mathrm{E}$, Ladis $\mathrm{V}$. The efficacy of iron chelator regimes in reducing cardiac and hepatic iron in patients with thalassemia major : a clinical observational study. J Cardiovasc Magn Reson.
2009;11:20.

18. Departemen Ilmu Kesehatan Anak Rumah Sakit Cipto Mangunkusumo. Data Pusat Thalassemia. Jakarta: 2011.

19. Cappelini MD, Cohen A, Eleftherlou A, Piga A, Porter J, Taher A. Guidelines for the clinical management of thalassemia. Proceedings from the Thalassemia International Federation; 2000; Athens.

20. Kirk P, Roughton M, Porter JB, Walker JM, Tanner MA, Patel J, et al. Cardiac T2* magnetic resonance for prediction of cardiac complications in thalassemia major. Circulation. 2009;120:1961-8.

21. Anderson LJ, Holden S, Davies B. Cardiovascular T2* magnetic resonance for the early diagnosis of myocardial iron overload. Eur Heart J. 2001;22:2171-9.

22. Anggriawan SL. Korelasi antara nilai cardiovascular T2* magnetic resonance dengan fungsi dan massa ventrikel kiri pada pasien talasemia mayor dengan kelebihan zat besi. Tesis Spesialis II Kardiologi Anak Departemen IKA FKUI [dissertation]. [Jakarta]: Universitas Indonesia; 2010.

23. Vogel M, Anderson LJ, Holden S, Deanfield JE, Pennell DJ, Walker JM. Tissue doppler echocardiography in patients with thalassemia detects early myocardial dysfunction related to myocardial iron overload. Eur Heart J. 2003;24:113-9.

24. George JC, Hoit BD. Non-invasive testing for cardiac dysfunction. [cited 2011 August 8]. Available from: www.mhprofessional. com/downloads/products/.../orourke_ch05.pdf-.

25. Kimball TR, Michelfelder EC. Echocardiography. In: Allen HD, Driscoll DJ, Shaddy RE, Feltes TF, editors. Moss and Adam's heart disease in infants, children, and adolescents, including the fetus and young adult. $7^{\text {th }}$ ed. Philadelphia: Lippincott Williams and Wilkins; 2008. p. 95-162.

26. Ho CY, Solomon SD. A clinician's guide to tissue Doppler imaging. Circulation. 2006;113:e396-8.

27. Gorcsan J. Tissue Doppler echocardiography. [cited 2011 Jan 21]. Available from: http://www.uptodate.com/patients/ content/topic.do?topicKey $=\sim$ z77zul3mIt/t1tR

28. Khraiche D, Pellerin D. Tissue Doppler, Doppler strain, and non-Doppler strain: tips, limitations, and applications. In: Nihoyannopoulos P, Kisslo J, editors. Echocardiography. London: Springer-Verlag; 2009. p.79-85.

29. Aypar E, Alehan D, Hazirolan T, Gumruk F. The efficacy of tissue Doppler imaging in predicting myocardial iron load in patients with beta-thalassemia major: correlation with $\mathrm{T} 2 *$ cardiovascular magnetic resonance. Int J Cardiovasc Imaging. 2010;26:413-21.

30. Madiyono B, Moeslichan Mz S, Sastroasmoro S, Budiman I, Purwanto HS. Perkiraan besar sampel. In: Sastroasmoro S, Ismael S, editors. Dasar-dasar metodologi penelitian klinis. 
Rosalina Josep et al: Cardiac dysfunction in thalassemia major patients using iron-chelating agents

$2^{\text {nd }}$ ed. Jakarta: Sagung Seto; 2002. p. 259-87.

31. Kremastinos DT, Tsetsos GA, Tsiapras DP, Karavolias GK, Ladis VA, Kattamis CA. Heart failure in B-thalassemia : a 5-year follow-up study. Am J Med. 2001;111:349-54.

32. Harada K, Orino T, Yasuoka K, Tamura M, Takada G. Tissue Doppler imaging of left and right ventricles in normal children. Tohoku J Exp Med. 2000;191:21-9.

33. Chahal NS, Lim TK, Jain P, Chambers JC, Kooner JS, Senior R. Normative reference values for the tissue Doppler imaging parameters of left ventricular function: a population-based study. Eur J Echocardiogr. 2010;11:51-6.

34. Henein M, Lindqvist P, Francis D, Morner S, Waldenstrom A, Kazzam E. Tissue Doppler analysis of age-dependency in diastolic ventricular behaviour and filling: a cross-sectional study of healthy hearts (The Umea general population heart study). Eur Heart J. 2002;23:162-71.

35. Sun JP, Popovic ZB, Greenberg NL, Xiao FX, Asher CR, Stewart WJ, et al. Non-invasive quantitification of regional myocardial function using Doppler-derived velocity, displacement, strain rate, strain in healthy volunteers: effects of aging. J Am Soc Echocardiogr. 2004;17:132-8.

36. Swaminathan S, Ferrer PL, Wolff GS, Gomez-Marin O, Rusconi PG. Usefulness of tissue Doppler echocardiography for evaluating ventricular function in children without heart disease. Am J Cardiol. 2003; 91:570-4.

37. Nagueh SF, Appleton CP, Gillebert TC, Marino PN, Oh JK, Smiseth OA, et al. EAE / ASE recommendations for the evaluation of left ventricular diastolic function by echocardiography. Eur J Echocardiogr. 2009;10:165-93.

38. Quinones MA. Evaluation of intracardiac filling pressure. In: Klein AL, Garcia MJ, editors. Diastology: clinical approach to diastolic heart failure. Philadelphia: Saunders; 2008. p. 187.

39. Appleton CP. Evaluation of diastolic function by twodimensional and Doppler assessment of left ventricular filling including pulmonary venous flow. In: Klein AL, Garcia MJ, editors. Diastology : clinical approach to diastolic heart failure. Philadelphia: Saunders; 2008. p. 119-32.

40. Reynolds T. Left ventricular diastolic function. In: Reynolds T, editor. The pediatric echocadiographer's pocket reference. $3^{\text {rd }}$ ed. Phoenix: Arizona Heart Institute; 2002. p. 311-4, $342-3$.

41. Otto CM. Classification of diastolic dysfunction (table). In: Otto CM, Schwaegler RG, editors. Echocardiography review guide. $1^{\text {st }}$ ed. Philadelphia: Saunders; 2007. p. 94.

42. Silvilairat S, Sittiwangkul R, Pongprot Y, Charoenkwan P,
Phornphutkul C. Tissue Doppler echocardiography reliably reflects severity of iron overload in pediatric patients with B-thalassemia. Eur J Echocardiogr. 2008;9:368-72.

43. Bosi G, Crepaz R, Gamberini MR, Fortini M, Scarcia S, Bonsante E, et al. Left ventricular remodelling and systolic and diastolic function in young adults with B-thalassemia major: a Doppler echocardiographic assessment and correlation with haematological data. Heart. 2003;89:762-6.

44. Galanello R, Origa R. Beta-thalassemia. Orphanet J Rare Dis. 2010;5:11.

45. Piga A, Longo F, Duca L, Roggero S, Vinciguerra T, Calabrese $\mathrm{R}$, et al. High non-transferrin bound iron levels and heart disease in thalassemia major. Am J Hematol. 2009;84:29. 33.

46. Delea TE, Edelsberg J, Sofrygin O, Thomas SK, Baladi JF, Phatak PD, et al. Consequences and costs of noncompliance with iron chelation therapy in patients with transfusiondependent thalassemia : a literature review. Transfusion. 2007;47:1919-29.

47. Ommen SR, Nishimura RA, Appleton CP, Miller FA, Oh JK, Redfield MM, et al. Clinical utility of Doppler echocardiography and tissue Doppler imaging in the estimation of left ventricular filling pressures: a comparative simultaneous Doppler-cathetherization study. Circulation. 2000;102:1788-94.

48. Lau KC, Li AM, Hui PW, Yeung CY. Left ventricular function in beta-thalassemia major. Arch Dis Child. 1989;64:104651.

49. Spirito P, Lupi G, Melevendi C, Vecchio C. Restrictive diastolic abnormalities identified by Doppler echocardiography in patients with thalassemia major. Circulation. 1990;82:8894.

50. Kremastinos DT, Tsiapras DP, Tsetsos GA, Rentoukas EI, Vretou HP, Toutouzas PK. Left ventricular diastolic Doppler characteristics in $\beta$-thalassemia major. Circulation. 1993;88:1127-35.

51. Gharzuddine WS, Kazma HK, Nuwayhid IA, Bitar FF, Koussa SF, Moukarbel GV, et al. Doppler characterization of left ventricular diastolic function in B-thalassaemia major, evidence for an early stage of impaired relaxation. Eur J Echocardiogr. 2002;3:47-51.

52. Moyssakis I, Tzanetea R, Tsaftaridis P, Rombos I, Papadopoulos DP, Kalotychou V, et al. Systolic and diastolic function in middle-aged patients with sickle beta-thalassaemia: an echocardiographic study. Postgrad Med J. 2005;81:711-4. 